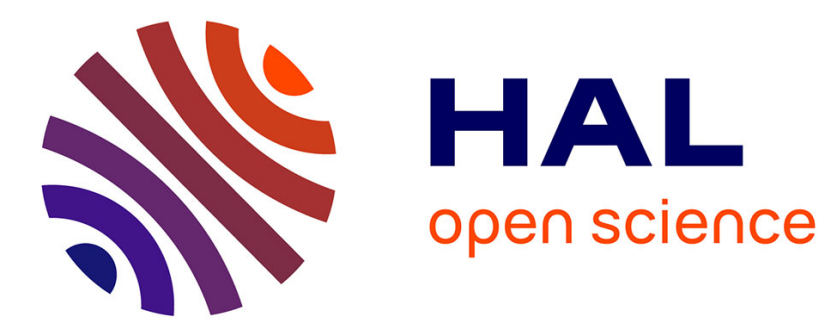

\title{
Solar Thermoelectric System with Biomass Back-up
}

José Teixeira Gonçalves, Cristina Inês Camus, Stanimir Stoyanov Valtchev

\section{To cite this version:}

José Teixeira Gonçalves, Cristina Inês Camus, Stanimir Stoyanov Valtchev. Solar Thermoelectric System with Biomass Back-up. 8th Doctoral Conference on Computing, Electrical and Industrial Systems (DoCEIS), May 2017, Costa de Caparica, Portugal. pp.358-369, 10.1007/978-3-319-560779_35. hal-01629603

\section{HAL Id: hal-01629603 https://hal.inria.fr/hal-01629603}

Submitted on 6 Nov 2017

HAL is a multi-disciplinary open access archive for the deposit and dissemination of scientific research documents, whether they are published or not. The documents may come from teaching and research institutions in France or abroad, or from public or private research centers.
L'archive ouverte pluridisciplinaire HAL, est destinée au dépôt et à la diffusion de documents scientifiques de niveau recherche, publiés ou non, émanant des établissements d'enseignement et de recherche français ou étrangers, des laboratoires publics ou privés.

\section{(c)(1)}

Distributed under a Creative Commons Attribution| 4.0 International License 


\title{
Solar Thermoelectric System with Biomass Back-up
}

\author{
José Teixeira Gonçalves ${ }^{1}$, Cristina Inês Camus ${ }^{2}$ and Stanimir Stoyanov Valtchev ${ }^{1}$ \\ ${ }^{1}$ NOVA University of Lisbon - Faculty of Sciences and Technology \\ Dep. Eng, Electrotecnica, 2829-516 Caparica, Portugal \\ jt.goncalves@campus.fct.unl.pt, ssv@fct.unl.pt \\ ${ }^{2}$ Politechnic Institut of Lisbon - Superior Institute of Engineering \\ Dep. Eletric Energy and Automation, Lisbon, Portugal \\ ccamus@deea.isel.pt
}

\begin{abstract}
With the objective of having a solar thermoelectric system, running for 24 hours a day along the different seasons of the year it is necessary to dimension the adequate storage and back-up systems. The choice of the back-up source of energy depends on how sustainable the power plant should be. In this study, the choice was the use of biomass in order to have a $100 \%$ renewable power plant. The selected site was the Alentejo region (Portugal). The local Direct Normal Irradiation (DNI) data was used to simulate with the System Advisor Model program (SAM) considering a solar system with north field and molten salt storage. The system needs no back-up during three months in a year. The use of biomass pellets is a viable alternative because it makes the power plant $100 \%$ renewable and dispatchable without loss of energy due to over-dimension of the expensive solar field and molten storage system.
\end{abstract}

Keywords: Solar, Thermoelectric, Backup, Biomass and Pellets.

\section{Introduction}

The need to increase the use renewable energy continues in the environmental policy of every country. Climate change keeps being an important issue and all research and investment go into the direction of the Carbon-free technologies.

One of the technologies that has denote an increase in sunny countries is the concentrated solar thermal (CSP) that converts the direct solar irradiation (DNI) into thermal energy through directional mirrors and a receiver. This thermal energy can be stored in molten salt tanks and then converted into electrical energy. The CSP technologies vary with the form of DNI concentration at the receiver. There are four types of CSP: Cylindrical-parabolic collectors, CCP; parabolic dish Stirling; linear Fresnel and central tower receiver [1], [2]. This technology has a high cost, and still needs feed-in tariffs in order to be economically viable.

The central tower solar thermal technology has reached commercial maturity and is expanding. In development since 1980, after the pioneering experience of the Solar I and Solar II in the US and Almeria Platform in Spain during the period 2000-2010 [3]. Currently, the largest power plant in the world with this type of technology is the Ivanpah with $377 \mathrm{MW}$ (California, U.S.A.) [4]. 
The storage technology is very important to able the power plant to generate for longer periods [2], as it is the case of Gemasolar (a solar tower with circular field) that was the first in the world to run 24 hours a day, thanks to the addition of storage and back-up system [5]. The 24 hours a day operation is just possible during a few summer periods with only the energy of the DNI and storage. In winter periods the system needs to add another technology to extend over the period, thereby making a hybrid system, but this addition is often made with oil products or natural gas. This makes the power plant less clean.

With this vision comes the main issue. How to make the CSP system that is completely renewable and clean, work 24 hours a day both in summer and winter periods?

The objective of this work is to study the use of biomass as a back-up for a CSP system central tower with north field and storage to operate 24 hours a day.

\section{Relationship to Smart Systems}

This work demonstrates that a hybrid system such as a thermoelectric solar tower with storage and biomass back-up system can operate 24 hours a day, both in summer and in winter and respect the clean and renewable way. Thermoelectric solar systems work automatically, from the solar concentrators drive process (following the sun orientation) [6] thermal fluid process (controlling the valves, the heat transfer fluid, HTF flows, thermal storage, etc.) [7] and the electrical system (controlling the power delivered to the grid, the power consumed in the system, etc.), it is noted that the system is fully automatic and intelligent, so it is important that the back-up system the pellets to be implemented is automatic [8]. The implementation of this automatic back-up system with pellets has several advantages:

- There is no need of human power to drive the biomass system.

- The system works in real time, it allows operation without interruption.

- The power supply is 24 hours a day, in winter and in summer.

- This allows the two systems to be operated automatically in only an operating room or other type of control.

The main contribution to the smart system is that the back-up biomass system works automatically, i.e., from the processing control when the thermoelectric solar system requires thermal power, the system actuates automatically (smart) to inlet the pellet biomass to the boiler which triggers combustion, transferring the thermal energy released from combustion to the overall system. All these processes are automated and help in the system reliability to have a safe and non-stop operation.

\section{State of Art}

There are basically four types of CSP, the cylindrical-parabolic collectors, CCP; parabolic dish Stirling; linear Fresnel and central tower receiver. 
The elements that differ in each CSP technology are mainly the solar field and receiver. Then they can have heat storage and heat exchanger (depending on the type of CSP and heat transfer fluid, HTF) and finally to convert thermal energy into electric energy a power unit is required.

The system studied in this work was the cavity tower receptor. A remarkable advantage of this technology (central tower solar thermoelectric) compared to other CSP technologies, such as linear Fresnel parabolic or disc is that the receiver operates at a higher thermal efficiency. This is due to the fact that all heliostats concentrate the DNI to a point (surface receptor) [9], thereby raising the operating temperature [10] (which aids in hybridization). The rapid growth of this technology is due, in large part, to this advantage. This type of system has also reached the stage of commercial maturity and is expanding.

\subsection{Description and Operation of the Thermoelectric Solar System with Biomass Backup}

The following key elements will be needed for the system to function: heliostats, tower and receiver, storage tank, power block (heat exchanger, turbine steam, electrical generator, condenser, water pumps, etc.) and boiler for pellets. The proper integration of all elements allows the correct operation of the system. Figure 1 shows the proposal of the system to be dimensioned, it shows all the elements already mentioned and we can observe that the structure of the field north the tower, allows to add the system of storage of the biomass to pellets to the south of the tower.

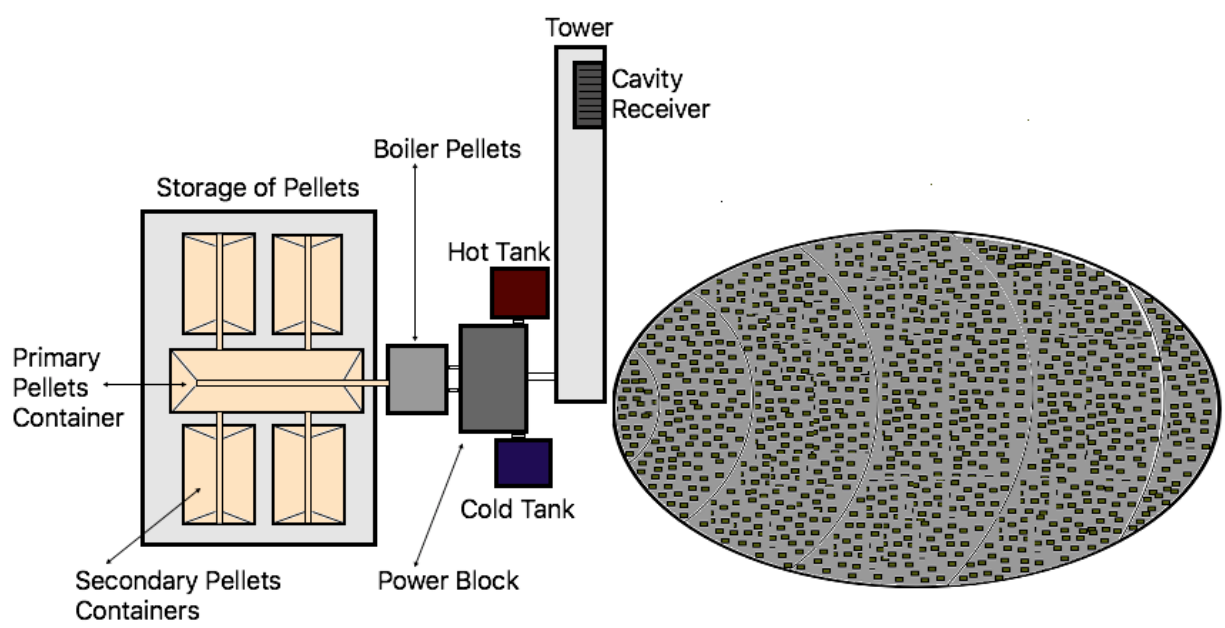

Heliostats Field

Fig. 1. Constitution of the complete structure of the proposed thermoelectric solar system with biomass backup. 


\subsubsection{Boiler of Pellets}

The pellet boiler is basically a furnace that operates automatically, it is made of tubes that serve as a heat exchanger, the combustion chamber, the pellets storage, the rook wiper carrier, air pump, etc. The boiler operating principle is shown in Figure 2.

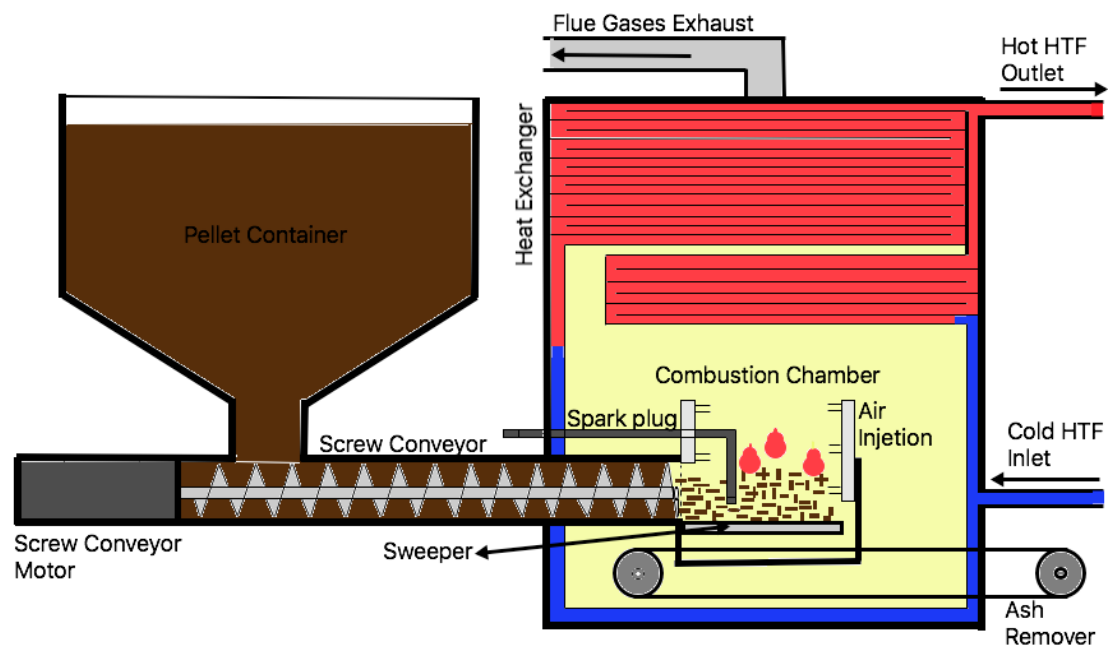

Fig. 2. Operating principle of the pellets boiler.

\subsubsection{Pellets}

The fuel pellets are completely natural as they are made primarily from wood chips and sawdust, but can also be made with corn cobs, wheat bran, rice husks, leaves, grasses, and other products.

The pellets are a type of densified biomass and therefore they have better physical and combustion characteristics compared to the raw biomass. Due to the size and shape of the cylinder that the pellets have, it becomes possible to automate the boiler running on this fuel, becoming competitive with gas, Diesel and fuel-oil boilers, since these boilers are also the systems of automatic ignition, automatic transport of the pellets to the combustion chamber, the ash removal mechanism automatic cleaning of the heat exchanger and others. The production of pellets adds the possibility of using different waste biomass into standard fuel systems [8].

In Europe and the United States of America biomass is largely used either on a domestic scale or on an industrial scale such as large thermoelectric power stations [11].

One can convert a coal plant to function with biomass, thereby reducing carbon dioxide emissions, or to create an original biomass power plant [11], [12].

The biomass plants can operate only with pellets, such as the Les Awirs plant (Belgium), which was converted from coal to work $100 \%$ with wood pellets, and consumes about 350,000 tons of pellets per year at 80MW power level [13], [14]. 


\subsubsection{Operating System}

The operating principle of this system which occurs automatically, can be described in two periods: The first period consists of the system operation with Direct Normal Irradiation (DNI) and storage and the second period the controlling of biomass combustion to provide the lack of thermal energy to the system (period 2) [15], [16], [17], as illustrated in Figure 3.

Period 1: The Direct Normal Irradiation, DNI, reaches the surface of the heliostat, which acts as a mirror, deflecting or reflecting the sun's rays to the receiver. This causes an increased solar concentration which in turn increases the temperature (thermal energy). This temperature is transferred to a heat transfer fluid (in the case molten salt), known as heat transfer fluid, HTF. If the system has two circuits (one primary and one secondary), the molten salt (HTF) only circulates through the primary circuit.

The primary circuit has two storage tanks: A cold and a hot tank, wherein the HTF flows with the aid of hydraulic pumps. The HTF leaving the cold tank, travels through the tube to the top of the tower reaching the receptor where its temperature rises from approximately $290^{\circ} \mathrm{C}$ to $575^{\circ} \mathrm{C}$. Then it is transferred to the hot tank, where it can be stored and, subsequently, the fluid leaves the hot tank and passes through a heat exchanger to be conducted again to the cold tank where the same process continues (a cycle).

The heat exchanger has the function to transfer the thermal energy from the primary circuit to the secondary circuit. In the secondary circuit the working fluid (water) rises its temperature changing from a liquid state into a vapor state. The vapor flows through a steam turbine, which converts kinetic energy into mechanical rotary energy. This vapor passes then through a condenser to become saturated liquid and continues its secondary circuit of the cycle. The rotating mechanical energy is converted into electricity by an electric generator coupled to the turbine. The electricity is then directed to a transformer, which increases the voltage lowering the current, so it can be transported by electric cables minimizing transmission losses of energy.

Period 2: In the period when there is neither DNI nor thermal energy stored in the hot tank, comes into operation the biomass back-up system to transfer the needed thermal energy to the HTF of the primary circuit. The stored pellets are transported by an automatic system in the boiler, into the furnace (above a grid), where its ignition is done by an automatic system (an electric resistance). Through this process the biomass is combusted in the combustion chamber (furnace). The heat released by the combustion process is then transferred to the HTF through the walls, which can be called a heat exchanger. Consequently, the HTF exits the boiler with sufficient thermal energy and goes to the system where it is transferred to the secondary circuit through the heat exchanger and then converted to electricity. 


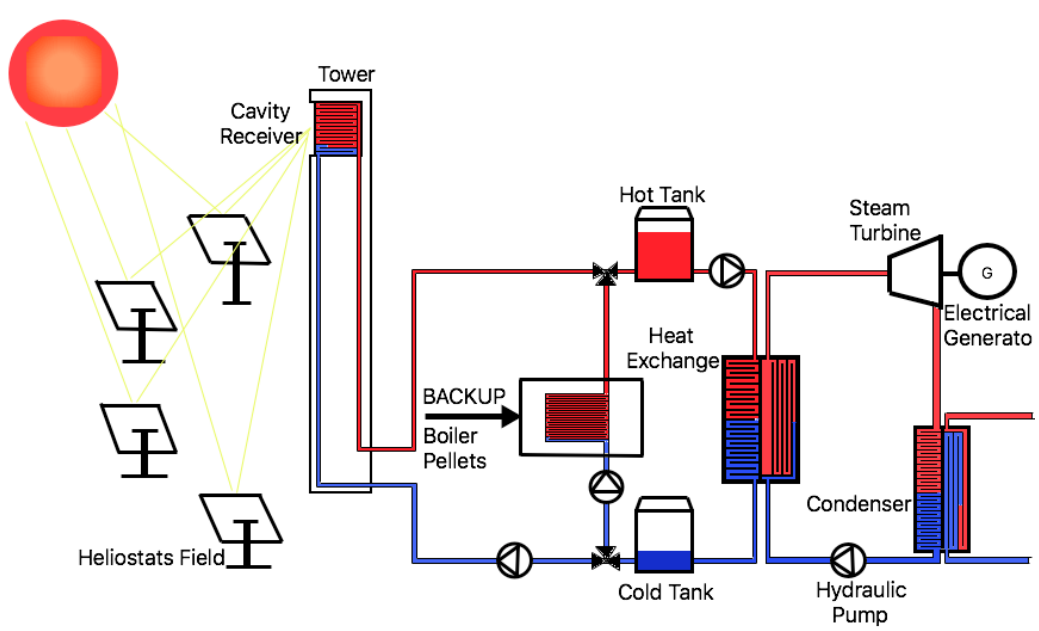

Fig. 3. Operating principle of the Solar thermoelectric tower with back-up with biomass.

\section{Research Contribution and Innovation}

Some existing solar systems work with back-up of various forms of energy, such as Gemasolar 20 MW (Spain) that adds a fossil fuel back-up (natural gas) for $15 \%$ of the annual energy generated by the plant [18], [19]. There are no CSP plants currently running with biomass back-up. This fact makes this work innovative on the following points:

- An automatic pellet boiler biomass (combustion) system works together with a thermoelectric solar system (north field) in a hybrid way ensuring that the system operates 24 hours a day, both in summer and in winter.

- A method to simulate with the System Advisor Model (SAM), a hybrid thermoelectric solar system and biomass, as far as the SAM software does not have a specific option for hybridization throughout the year.

\section{Methodology and Simulation}

The simulation was performed on System Advisor Model, SAM (the selected version was the "Version 01/14/2014"), with six (6) blocks to enter the parameters for processing, namely the City and climatic resources, Heliostat field, solar tower and receiver, power block (Rankine Cycle thermal dispatch control and electric generator), thermal storage and system costs. The parameters used in these blocks are described in Table 1. Some points should be described in greater detail, such as the location and climatic resort, the thermal dispatch control system and the pellets' system. As a reference, it is possible to analyze some examples of simulations of CSP performed in SAM in [18]. 
Table 1. Parameters used in system simulation.

\begin{tabular}{|c|c|c|}
\hline Block & Parameters & Values \\
\hline \multirow[t]{3}{*}{ Location and Resource } & $D N I(k W h / m 2)$ year & 2319,4 \\
\hline & Latitude & 38,165 \\
\hline & Longitude & $-7,195$ \\
\hline \multirow[t]{2}{*}{ Heliostats Field } & Heliostat area $(\mathrm{m} 2)$ & 91 \\
\hline & Number of heliostats & 2067 \\
\hline \multirow[t]{5}{*}{ Tower and Receiver } & Receiver type & Cavity \\
\hline & External pipe diameter $(\mathrm{mm})$ & 40 \\
\hline & Pipe Wall Thickness (mm) & 1,25 \\
\hline & Tower Height $(m)$ & 127,11 \\
\hline & Tube material (stainless steel) & AISI 316 \\
\hline \multirow[t]{3}{*}{ Power Cycle } & Drawing Gross capacity (MW) & 20 \\
\hline & Conversion Efficiency (\%) & 41,2 \\
\hline & Type condensation & $\mathrm{Ar}$ \\
\hline \multirow[t]{5}{*}{ Thermal storage } & Type of storage & 2 tanks \\
\hline & Hours of Storage (hrs) & $0-11$ \\
\hline & Storage volume (m3) & 2514,98 \\
\hline & Initial hot HTF Tem. $\left({ }^{0} \mathrm{C}\right)$ & 574 \\
\hline & Initial cold HTF Tem. $\left({ }^{\circ} \mathrm{C}\right)$ & 290 \\
\hline \multirow{9}{*}{ Direct Capital Costs } & Site improvements $(\$ / m 2)$ & 15 \\
\hline & Heliostats field $(\$ / \mathrm{m} 2)$ & 170 \\
\hline & Balance of plant $(\$ / \mathrm{kW})$ & 350 \\
\hline & Power block $(\$ / \mathrm{kW})$ & 1200 \\
\hline & Storage $(\$ / k W h t)$ & 27 \\
\hline & Boiler pellets $(\$ / k W e)$ & 540 \\
\hline & Fixed tower cost $(\$)$ & 3000000 \\
\hline & Receiver reference cost (\$) & 110000000 \\
\hline & Contingencies (\%) & 7 \\
\hline \multirow[t]{5}{*}{ Indirect Capital Costs } & EPC and ower costs (\%) & 11 \\
\hline & Total land cost (\$ /acre) & 10000 \\
\hline & Sales tax of $(\%)$ & 5 \\
\hline & Direct cost of sales (\%) & 80 \\
\hline & Cost of $O \& M(\$ / \mathrm{kW})$ & 65 \\
\hline
\end{tabular}

\section{$1^{\circ}$ - Location and Climatic Resources}

In this block, the location where we want to install the plant was set up. The site was near a village in the Alentejo region, with the coordinates described in Table 1. The data from the DNI were extracted from the Photovoltaic platform Geographic Information System (PVGIS), thus having the monthly average data, considered these data as daily for each month and there was thus obtained in an Excel table with 8760 values of annual DNI. It was then possible to create a new database, transferring some values of a model ("Évora database" as stored in the program) in EPW format to Excel and complete with the extracted DNI from PVGIS. Later this database, in Excel, was converted to the executable TMY3 format to enter as an input to the SAM software.

\section{$2^{\circ}$ - Thermal Dispatch Control System}

The thermal clearance control system is an automatic control of thermal energy that is routed to the power block. This control is registered to a table where the lines refer to the months of the year and 24 columns refer to the daily hours (Table 2). 
In this paper it is proposed a thermal model order strategy so that only $50 \%$ of the rated power is generated when there is no DNI, which means that without DNI the power supply is of only $10 \mathrm{MW}$ instead of $20 \mathrm{MW}$. This will cause the stored energy to last during a double period.

When the source is biomass it will also only be supplied $50 \%$ of plant capacity, which means that during the back-up period, the power supply is 10MW. This will minimize the cost of biomass and cause the system to work 24 hours a day. Table 2 shows the order made for each month of the year.

Table 2. Strategic model for the control of thermal dispatch system.

\begin{tabular}{|c|c|c|c|c|c|c|c|c|c|c|c|c|c|c|c|c|c|c|c|c|c|c|c|c|}
\hline & $\underline{\underline{E}}$ & $\underset{\Xi}{\underline{్}}$ & E్ & E్ & E & E్ & Е & E & E్ & Е & 틍 & \begin{tabular}{|l|}
$\underline{\text { 至 }}$ \\
\end{tabular} & \begin{tabular}{|l|} 
E \\
N
\end{tabular} & $\underline{\mathrm{E}}$ & 至 & 总 & छ్ & E్ & E⿱ & E & $\begin{array}{l}\mathrm{E} \\
\stackrel{\infty}{\infty}\end{array}$ & 틍 & \begin{tabular}{|l|}
$\mathrm{E}$ \\
\end{tabular} & 豆 \\
\hline Jan & 3 & 3 & 3 & 3 & 3 & 3 & 3 & 3 & 3 & 3 & 3 & 1 & 1 & 1 & 1 & 1 & 3 & 3 & 3 & 3 & 3 & 3 & 3 & 3 \\
\hline Feb & 3 & 3 & 3 & 3 & 3 & 3 & 3 & 3 & 3 & 1 & 1 & 1 & 1 & 1 & 1 & 1 & 1 & 1 & 3 & 3 & 3 & 3 & 3 & 3 \\
\hline Mar & 3 & 3 & 3 & 3 & 3 & 3 & 3 & 3 & 1 & 1 & 1 & 1 & 1 & 1 & 1 & 1 & 1 & 1 & 3 & 3 & 3 & 3 & 3 & 3 \\
\hline Apr & 3 & 3 & 3 & 3 & 3 & 3 & 3 & 3 & 1 & 1 & 1 & 1 & 1 & 1 & 1 & 1 & 1 & 1 & 1 & 3 & 3 & 3 & 3 & 3 \\
\hline May & 3 & 3 & 3 & 3 & 3 & 3 & 3 & 2 & 1 & 1 & 1 & 1 & 1 & 1 & 1 & 1 & 1 & 1 & 2 & 2 & 2 & 2 & 2 & 3 \\
\hline Jun & 2 & 2 & 2 & 2 & 2 & 2 & 2 & 2 & 1 & 1 & 1 & 1 & 1 & 1 & 1 & 1 & 1 & 2 & 2 & 2 & 2 & 2 & 2 & 2 \\
\hline Jul & 2 & 2 & 2 & 2 & 2 & 2 & 1 & 1 & 1 & 1 & 1 & 1 & 1 & 1 & 1 & 1 & 1 & 1 & 1 & 1 & 1 & 1 & 2 & 2 \\
\hline Aug & 2 & 2 & 2 & 2 & 2 & 2 & 2 & 1 & 1 & 1 & 1 & 1 & 1 & 1 & 1 & 1 & 1 & 1 & 1 & 1 & 2 & 2 & 2 & 2 \\
\hline Sep & 2 & 3 & 3 & 3 & 3 & 3 & 3 & 3 & 1 & 1 & 1 & 1 & 1 & 1 & 1 & 1 & 1 & 1 & 1 & 2 & 2 & 2 & 2 & 2 \\
\hline Oet & 3 & 3 & 3 & 3 & 3 & 3 & 3 & 3 & 3 & 1 & 1 & 1 & 1 & 1 & 1 & 1 & 1 & 1 & 2 & 2 & 3 & 3 & 3 & 3 \\
\hline Nov & 3 & 3 & 3 & 3 & 3 & 3 & 3 & 3 & 3 & 3 & 1 & 1 & 1 & 1 & 1 & 1 & 1 & 1 & 3 & 3 & 3 & 3 & 3 & 3 \\
\hline Dec & 3 & 3 & 3 & 3 & 3 & 3 & 3 & 3 & 3 & 3 & 1 & 1 & 1 & 1 & 1 & 3 & 3 & 3 & 3 & 3 & 3 & 3 & 3 & 3 \\
\hline & 1 & 10 & & & & $\mathrm{NI}$ & & & 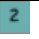 & $50^{\circ}$ & & & & & & & & 4 & & J & & & & $\mathrm{K}-\mathrm{u}$ \\
\hline
\end{tabular}

Thus, one can make an assessment of how many hours the biomass will be running for each month (having an average 13.78 hour) and using the pellets in the system calculations.

\section{$3^{\circ}$ - The Biomass System}

It was considered that the boiler has a standardized performance value of $\eta_{\text {boi }}=80.6 \%$.

The lower heating value (LHV) of the pellets is about 17000 $\mathrm{kJ} / \mathrm{kg}=4060.382 \mathrm{kcal} / \mathrm{kg}$. To calculate the amount of pellets consumed by the system it is sufficient to apply the following two steps:

1. Calculate the energy of the biomass $\left(E_{b i o}\right)$ pellets, which burns to produce the heat required for the system:

$$
E_{\text {bio }}=\frac{E_{\text {ther.m }}}{\eta_{\text {hoi }}}
$$

Where:

$\eta_{b o i}=$ Boiler performance

$E_{\text {ther.m }}=$ Monthly thermal energy, calculated with the following expression.

$$
E_{\text {ther.m }}=P_{\text {syst }} \times t_{\text {moy }} \times 860 \mathrm{kcal}
$$


$t_{m o y}=$ Monthly time given in hours.

$P_{\text {syst }}=$ Thermal power in the system.

1. Calculate the amount of pellets burning in the boiler $\left(C_{\text {pel.m }}\right)$.

$$
C_{p e l . m}=\frac{E_{b i o}}{L H V}
$$

\section{Results and Discussion}

\subsection{Annual Output of System with Backup of Biomass Pellets}

Figure 4 shows several energy conversion processes and system losses that occur. This figure shows the total thermal energy falling on the solar field to power into the grid.

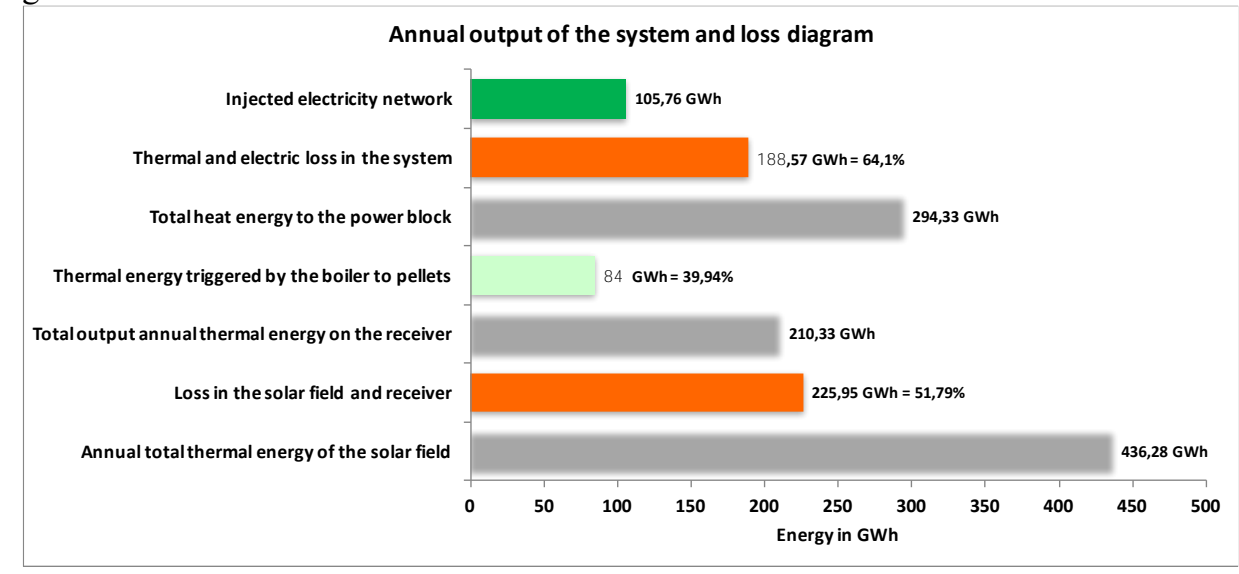

Fig. 4. Summary of the annual production of the system and loss diagram.

The total annual thermal incident energy in the solar field is $436.28 \mathrm{GWh}$, this energy is thus forwarded to the receiver, causing a loss in the solar field and receiver of $225.95 \mathrm{GWh}$ which corresponds to $51.79 \%$. With this loss the total annual thermal energy output of the receiver is $210.33 \mathrm{GWh}$, which is directed to the power block. To the thermal energy of $210.33 \mathrm{GWh}$ in the HTF is added a thermal energy from the back-up system of $84 \mathrm{GWh}$ corresponding 39.94\%. Therefore, the total annual thermal energy power block is $294.33 \mathrm{GWh}$. This thermal energy is thus converted (after suffering thermal and electrical losses of 188.57) into electrical energy 105.67 GWh injected into the network. With these data, it can be said that the overall system performance is $19.57 \%$.

The energy injected into the network varies each month of the year (see Figure 5 left), and in July and august it is injected more energy in the network, about 10.77 GWh and 10.04 GWh respectively. The month with less injected energy is the month 
of January with only $7.27 \mathrm{GWh}$. This energy generation profile was attained due to the back-up system. Figure 5 (right), shows the amount of pellets each month that the system needs for the production of thermal energy necessary for the system to function in the absence of DNI and storage.

Note that the months with the highest consumption of biomass are January and December and in June, July and August no biomass is consumed, as during these months there is enough DNI to make the system work 24 hours a day.

The total amount of pellets per year that the system will need is about 24 thousand tons, which is less than the amount of pellets each of the three selected producers export (about 180 from 270 thousand tons) per year. These show that only a producer would be enough to power the system.
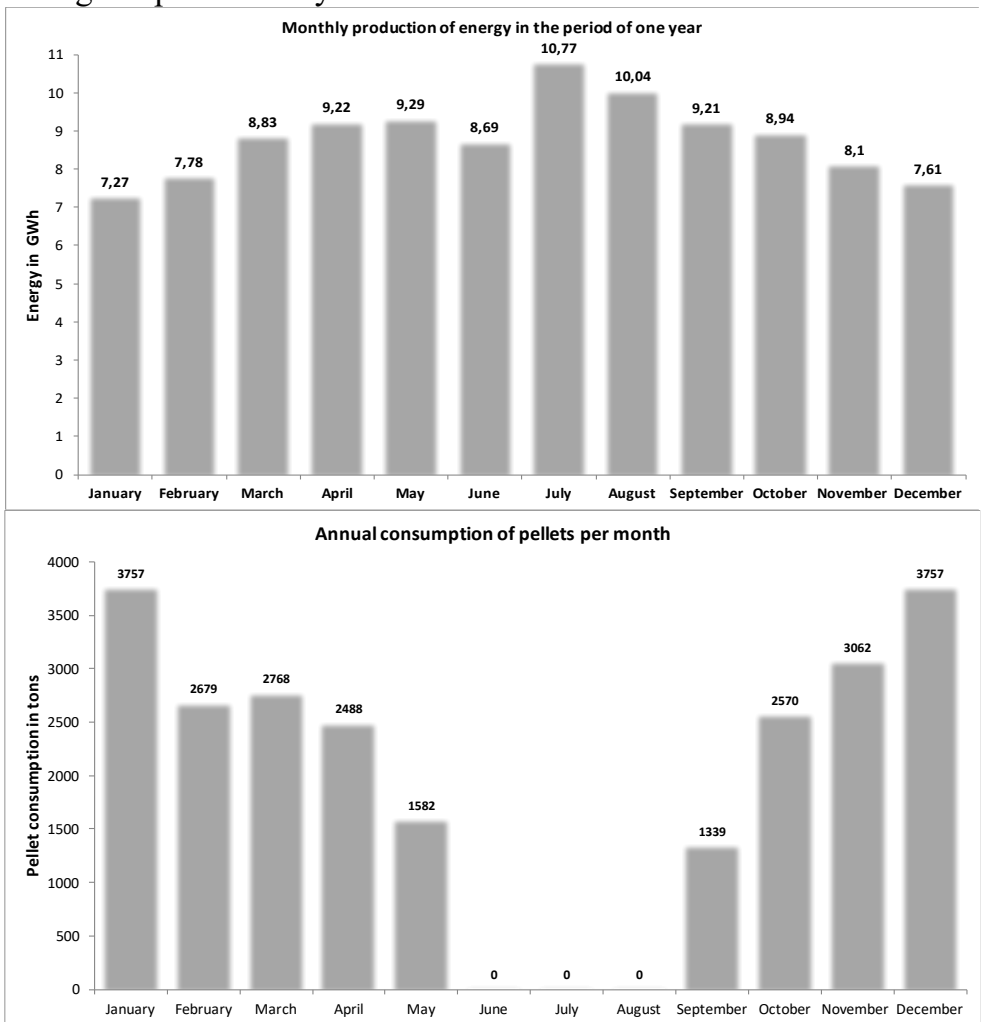

Fig. 5. Energy production per month and monthly consumption of pellets.

\subsection{Validation of the Results}

If we analyze the obtained results and compare with the values of central Gemasolar [18], which also have a power of 20MW and back-up system, we verify that many parameters are compatible such as: 
The thermal power generated by the receiver of the system under study is 116.505 MWt and Gemasolar is $120.752 \mathrm{MWt}$, this small difference is due to differences in receptor structure, availability of DNI and because the Gemasolar applies a higher multiplier of 2.5 than 2.4 in the study system.

The storage volume of Gemasolar $(3476.76 \mathrm{~m} 3)$ is greater than the system under study $(2514.98 \mathrm{~m} 3)$, that because the storage time is greater in Gemasolar, and 15 hours after the system under study is 11 hours.

The capacity factor is higher in Gemasolar (70.4\%), compared to that of the system under study (69.4\%), since the production of the system under study is lower (105 76 GWh), than that of Gemasolar (about 107.34 GWh).

These differences are reflected in the total system costs: $\$ 209,003,197.52$ for Gemasolar, and $\$ 155,901,171.55$ for the system under study. This difference is understandable if the price of the elements would be taken into account as already mentioned.

To calculate the efficiency of the system under study the example of the central Les Awirs in Belgium was analyzed, which runs on $100 \%$ wood pellets. It consumes about 350,000 tons of pellets per year and the output power is $80 \mathrm{MW}$. The analyzed above system in this case should have power of $10 \mathrm{MW}$ and should consume about 43750 tons/year. If we consider the energy of 43750 tons/year and the power of 10 MW, i.e. 24 hours producing $10 \mathrm{MW}$, and reduce the working time to the average of 13.78 hours a day, in that case the quantity of pellets decreases from the value of 43750 tons/year to 25120 t/year, which is compatible with the pellet consumption in the system under study $24000 \mathrm{t} /$ year.

\section{Conclusion}

This paper analyses the implementation of an automatic back-up system based in biomass pellets to support a solar thermoelectric system with north field during the less available radiation months. The interconnection of all the elements in order to form a system that converts the DNI and biomass pellets into electricity, was modelled and tested for a $20 \mathrm{MW}$ power plant in Alentejo (Portugal). The design was executed simultaneously by SAM software and in Excel (back-up pellets).

A comparison made of simulated values in the SAM, with the actual values of Gemasolar (obtained from a simulation made in the laboratory of renewable energy in the United States of America, USA), demonstrates a reasonable approximation of these simulated values, both in technical parameters and in economic parameters.

The annual figures were all generated in the SAM and Excel, which demonstrates a certain energy balance, entering thus the system about DNI $=2319.4 \mathrm{kWh} / \mathrm{m}^{2}$ and 24000 tons of pellets per year, converted to $105,76 \mathrm{GWh}$ of electricity per year, which is a feasible value for this type of system. In terms of back-up, the biomass demonstrates to be viable, increasing the energy produced and thus the capacity factor from that of $49.1 \%$ to $69.4 \%$, but the use of biomass also increases the overall yield of $16.99 \%$ to $19.57 \%$. 


\section{References}

1. García-Segura, A., Fernández-García, A., Ariza, M. J., Sutter, F., \& Valenzuela, L.: Durability studies of solar reflectors: A review. Renewable and Sustainable Energy Reviews, 62, 453-467 (2016)

2. Khan, J., \& Arsalan, M. H.: Solar power technologies for sustainable electricity generationA review. Renewable and Sustainable Energy Reviews, 55, 414-425 (2016)

3. Boudaoud, S., Khellaf, A., \& Mohammedi, K.: Solar tower plant implementation in northern algeria: technico economic assessment. In Modeling, Simulation and Applied Optimization (ICMSAO), 2013 5th International Conference on (pp. 1-6). IEEE (2013, April)

4. IVANPANH Solar Electric Generating System, http://www.ivanpahsolar.com

5. Torresol Energy, http://www.torresolenergy.com/TORRESOL/gemasolar-plant/en

6. Kumar, M., \& Krishna, D. J.: Analytical and numerical study to assess the solar flux on a heliostat based central receiver. In Energy Efficient Technologies for Sustainability (ICEETS), 2016 International Conference on (pp. 762-767). IEEE (2016, April)

7. Tehrani, S. S. M., \& Taylor, R. A.: Off-design simulation and performance of molten salt cavity receivers in solar tower plants under realistic operational modes and control strategies. Applied Energy, 179, 698-715 (2016)

8. Monteiro, E., Mantha, V., \& Rouboa, A.: The feasibility of biomass pellets production in Portugal. Energy Sources, Part B: Economics, Planning, and Policy, 8(1), 28-34 (2013)

9. Wagner, M. J.: Simulation and predictive performance modeling of utility-scale central receiver system power plants. University of Wisconsin--Madison (2008)

10. Boudaoud, S., Khellaf, A., Mohammedi, K., \& Behar, O.: Thermal performance prediction and sensitivity analysis for future deployment of molten salt cavity receiver solar power plants in Algeria. Energy Conversion and Management, 89, 655-664 (2015)

11. Johnston, C. M., \& van Kooten, G. C.: Economics of co-firing coal and biomass: An application to Western Canada. Energy Economics, 48, 7-17 (2015)

12. REVISTA DA MADEIRA - EDIÇÃO Nº137 - OUTUBRO DE 2013, http://www.remade.com.br/br/revistadamadeira_materia.php?num=1712\&su bject $=$ Pellets\&title=Demanda de pellets e biomassa no mercado europeu

13. Marchal, D.: Current developments on Belgian pellet market. Wels (Austria) (2007), http://valbiom.be/files/gallery/wels20071200481419.pdf

14. CENTRALE DES AWIRS 100\% biomasse, http://corporate.engie-electrabel.be/wpcontent/uploads/2016/03/12038_lesawirs_folder_fr_lr.pdf

15. Boudaoud, S., Khellaf, A., Mohammedi, K., \& Behar, O.: Thermal performance prediction and sensitivity analysis for future deployment of molten salt cavity receiver solar power plants in Algeria. Energy Conversion and Management, 89, 655-664 (2015)

16. Gonçalves, J. T.: Estudo técnico-económico de um sistema solar termoelétrico com back-up a biomassa (dissertation) (2015)

17. Hussain C.M.I, Norton. B. \& Du y. A.: Technological assessment of di erent solar-biomass systems for hybrid power generation in Europe. Renewable and Sustainable Energy Reviews (2016), doi:10.1016/j.rser.2016.08.016 (2016)

18. System Advisor Model (SAM) Case Study. Concentrating Solar Power Systems, https://sam.nrel.gov/case-studies

19. Amadei, C. A., Allesina, G., Tartarini, P., \& Yuting, W.: Simulation of GEMASOLARbased solar tower plants for the Chinese energy market: Influence of plant downsizing and location change. Renewable energy, 55, 366-373 (2013) 